\title{
Path Analysis: Maternal Determinants and Hair Zinc Levels as Predictors of Stunting and Developmental Disorders in Children Under Five
}

\author{
Nunik Ike Yunia Sari, Estin Gita Maringga
}

Midwifery Study Program, School of Health Sciences Karya Husada Kediri, East Java

\section{ABSTRACT}

Background: Stunting that occurs during childhood will have an impact on the condition of cognitive development in the future. The purpose of this study is to determine the risk factors that have a direct and indirect effect on the stunting and developmental disorders in children under five.

Subjects and Method: This was a case study located at Gurah Health Center, Kediri, East Java, from August $4^{\text {th }}$ to $29^{\text {th }}$ 2020. A sample size of 100 subjects was selected by randomly. The dependent variables were stunting and developmental disorders. The independent variables were maternal mid-upper arm circumference (MUAC), exclusive breastfeeding, low birth weight (LBW), infants birth length, and hair zinc levels. The data were measured by questionnaire. Hair zinc levels were tested in the laboratory. Quantitative data analysis used path analysis.

Results: Child development was directly and positively influenced by the maternal MUAC $(b=0.12 ; \mathrm{SE}=0.36 ; \mathrm{p}<0.001)$, birth weight $(b=$ 0.29; $\mathrm{SE}=0.15 ; \mathrm{p}=0.042)$, birth length $(\mathrm{b}=$ 0.37; $\mathrm{SE}=0.15 ; \mathrm{p}=0.011)$, breastfeeding $(\mathrm{b}=$ o.o8; $\mathrm{SE}=0.04 ; \mathrm{p}=0.033)$, stunting $(\mathrm{b}=-0.39$; $\mathrm{SE}=0.10 ; \mathrm{p}<0.001)$, and hair zinc level $(\mathrm{b}=$ $0.58 ; \mathrm{SE}=0.67$; $\mathrm{p}<0.001$ ). Hair zinc level was positively influenced by birth weight $(b=0.92$; $\mathrm{SE}=0.04 ; \mathrm{p}<0.001)$. Child development was indirectly influenced by exclusive breastfeeding, birth length, and zinc levels.

Conclusion: Child development is directly and positively influenced by the maternal MUAC, birth weight, birth length, breastfeeding, stunting, and hair zinc level. Hair zinc level is positively influenced by birth weight. Child development ias indirectly influenced by exclusive breastfeeding, birth length, and zinc levels.

Keywords: Maternal determinant factors, hair zinc levels, stunting, developmental disorders

\section{Correspondence:}

Nunik Ike Yunia Sari. Midwifery Study Program, School of Health Sciences Karya Husada Kediri. Jl. Soekarno Hatta 153 Pare Kediri, East Java. Email: agharda1502@gmail.com

\section{Cite this as:}

Sari NIY, Maringga EG (2021). Path Analysis: Maternal Determinant and Hair Zinc Levels as Predictors of Stunting and Developmental Disorders in Children Under Five. J Matern Child Health. 06(03): 314-326. https://doi.org/10.26911/thejmch.2021.06.03.06.

(7)(2) Journal of Maternal and Child Health is licensed under a Creative Commons Attribution-Non Commercial-Share Alike 4.0 International License.

\section{BACKGROUND}

Stunting was a nutritional problem in children, which was currently the concern of various parties. Stunting was a chronic under nutritional status during growth and development since early life (Guide, 2012).

Data from WHO in 2017 found that 22.2\% or around 150.8 million children under five experienced stunting, in which in this stunting case, $55 \%$ of children under five were found in Asian countries and nearly 2/5 of stunting cases in children in the world were in Southeast Asia region. Nearly half (47\%) of children under five who experienced stunting had come from countries with lower middle economies (WHO, UNICEF \& Group, 2018). Results of Basic Health Research (Riset Kesehatan 
Dasar, Riskesdas) in Indonesia in 2018 found that the number of children under five who experienced stunting was $30.8 \%$. Whereas in East Java Province in 2018, the stunting in children under five was $32.81 \%$ (Kesehatan Badan Penelitian dan Pengembangan Kesehatan Puslitbang Humaniora dan Manajemen Kesehatan, 2018). Based on this data, the East Java Provincial Government was focused on handling stunting in 12 regencies in 2019, one of which was in the Kediri Regency. One of the areas in Kediri Regency that had a stunting case was the Gurah Public Health Center. In 2019, the stunting case in the working area of the Gurah Public Health Center, Kediri Regency was $15.6 \%$ of the total number of children under five in the working area of the Gurah Health Center.

The causes of stunting in children under five were very diverse including maternal health, maternal age, history of low birth weight, history of infection, and environmental factors (Danaei et al., 2016). The results of other studies on stunting showed that deficiency of several micronutrients in children under five would increase the stunting in a child. According to Maggini et al. (2010) in Bening et al., (2017), Zinc was an important micronutrient in the body in cell growth, protein and DNA synthesis, energy metabolism, regulation of gene transcription, and influencing growth factor hormone). Zinc deficiency could cause the effects of the metabolite growth hormone (GH) to be inhibited so that the synthesis and secretion of IGF-1 (Insulin-Like Growth Factor 1) were reduced. Reduced IGF-1 secretion could lead to stunted growth and children become stunting (Park et al., 2017).

One of the effects of stunting was a developmental disruption in the future, the results of the study in China show that children who had experienced stunting would have lower intelligence (Li et al., 2016).

Kediri Regency was one of the areas receiving treatment to overcome stunting. Based on the background above, stunting was one of the nutritional problems in children under five that had to be addressed immediately. One of the efforts to overcome the stunting in children under five was to find risk factors for stunting in children under five, both directly and indirectly affecting the stunting. Based on the background above, this study took the title "Path Analysis: Maternal determinant factors and hair zinc levels as predictors of stunting and developmental disorders in children under five in Gurah District, Kediri Regency

The objective of this study was to analyze the effect of maternal determinant factors and hair zinc levels as predictors of the stunting and developmental disorders in children under five in Gurah Public Health Center area, Kediri Regency, East Java.

\section{SUBJECTS AND METHOD \\ 1. Study Design}

This study was conducted using case-control study by determining the group exposed to a disease first, then identifying the causes or risk factors for the disease. In this study, the case group selected was children under five with stunting and the control group was children under five with normal height. This study was conducted in several villages in the working area of the Gurah Health Center, Kediri, East Java. Study data collection was carried out on August $13^{\text {th }}$ to $29^{\text {th }} 2020$.

Respondents were divided into case and control groups according to the inclusion criteria in this study, with a ratio of at least 1: 2 between case and control groups. Fixed disease sampling was used to 
determine respondents in the case and control groups, in which the researcher selects respondents according to the objectives and needs of the study. In this study, the respondents selected were children under five with stunting and normal height. Samples were taken based on the inclusion criteria of the study, i.e., children under five, accompanied by parents or caregivers, parents allowed their children to become respondents. The study exclusion criteria were children in sick condition, children without hair. Samples were taken from four villages, with the number of samples according to their needs and conditions. Data were collected at posyandu and door to door if the sample was not met. Conditions of Covid 19 made it impossible to collect respondents at one time.

\section{Population and Sample}

The study population was all children under five in the working area of the Gurah Health Center. The sample in this quantitative study was 100 study subjects.

\section{Study Variables}

There were six variables in this study which consist of exogenous variables including mother's upper arm circumference, baby's birth weight, length at birth, and exclusive breastfeeding as well as endogenous variables including hair zinc levels, stunting, and developmental disorders.

\section{Operational Definition of Variables}

Maternal MUAC was a measure of the upper arm circumference of pregnant women when the first contact at ANC visits.

History of exclusive breastfeeding was the history of breastfeeding immediately after birth until the time of examination.

Infants birth length was the baby's body length measured immediately after birth.
Infants birth weight was the birth weight of the baby measured immediately after birth.

Hair zinc level was the zinc level checked using a hair specimen during the examination.

Stunting was the children's height measured at the time of the study.

Child developmental disorder was the child development progression score checked using developmental pre-screening questionnaire during the study.

\section{Study Instruments}

Data collection used developmental prescreening questionnaire sheets, laboratory tests, and measurements used microtoice. Stunting was measured using a microtoice. Measurement of hair zinc levels was carried out in the laboratory.

\section{Data Analysis}

Data processing was carried out by path analysis using Amos 22.

\section{RESULTS}

1. Sample Characteristics

The characteristic dimension of the child showed that of the 100 study subjects, there were 88 study subjects (88\%) aged $13-60$ months, 55 study subjects (55\%) were female, 72 study subjects (72\%) had a history of aterm gestational age, and 67 study subjects (67\%) had a height $\geq 145 \mathrm{~cm}$, 61 study subjects (61\%) had a history of $\mathrm{Hb}$ levels during normal pregnancy, 57 study subjects (57\%) had no history of infection.

\section{Univariate analysis}

The results of the descriptive statistics of continuous data in the form of mother's upper arm circumference, exclusive breastfeeding, LBW, Length at birth, hair zinc levels, and the dependent variables were stunting and developmental disorders could be seen in Table 2 . 
Sari et al./ Predictors of Stunting and Developmental Disorders

Table 1. Study subject characteristics

\begin{tabular}{llcc}
\hline Characteristics & \multicolumn{1}{c}{ Criteria } & N & \% \\
\hline Age & O-6 months old & 7 & 7 \\
& $7-12$ months old & 5 & 5 \\
Sex & 13-60 months old & 88 & 88 \\
Gestational Age & Male & 45 & 45 \\
& Female & 55 & 55 \\
& Premature & 10 & 10 \\
Maternal Height & Aterm & 72 & 72 \\
& Postdate & 18 & 18 \\
Hemoglobin level & $<145 \mathrm{~cm}$ & 33 & 33 \\
during pregnancy & $\geq 145 \mathrm{~cm}$ & 67 & 67 \\
History of Infection & $<11$ gr\% & 39 & 39 \\
& $\geq 11$ gr\% & 61 & 61 \\
\hline
\end{tabular}

Table 2. Univariate analysis of study variables

\begin{tabular}{llll}
\hline \multicolumn{1}{c}{ Variables } & \multicolumn{1}{c}{ Criteria } & N & \% \\
\hline Maternal MUAC & $\geq 23.5 \mathrm{~cm}$ & 78 & 78 \\
Birth weight & $<23.5 \mathrm{~cm}$ & 22 & 22 \\
& $\geq 2500$ grams & 56 & 56 \\
Birth length & $<2500$ grams & 44 & 44 \\
& $\geq 48 \mathrm{~cm}$ & 55 & 55 \\
Breastfeeding & $<48 \mathrm{~cm}$ & 45 & 45 \\
& Exclusive & 53 & 53 \\
Zinc Level & Non exclusive & 47 & 47 \\
\multirow{2}{*}{ Stunting } & $\geq 198 \mathrm{ppm}$ & 56 & 56 \\
& $<198 \mathrm{ppm}$ & 44 & 44 \\
Developmental Disorders & Normal & 53 & 53 \\
& Stunting & 47 & 47 \\
& Normal & 55 & 55 \\
\hline
\end{tabular}

The characteristic dimension of the child showed that of the 100 study subjects, there were 78 study subjects $(78 \%)$ had mother's upper circumference $\geq 23.5 \mathrm{~cm}, 56$ study subjects (56\%) had weight at birth $\geq 2500$ grams, 55 study subjects (55\%) had length

Table 3. Bivariate analysis of maternal determinant factors and hair zinc levels as predictors of developmental disorders

\begin{tabular}{lcc}
\hline Independent Variables & $\mathbf{r}$ & $\mathbf{p}$ \\
\hline Maternal MUAC & 0.12 & $<0.001$ \\
Birth weight & 0.29 & 0.042 \\
Birth length & 0.37 & 0.011 \\
Breastfeeding & 0.08 & 0.033 \\
Stunting & -0.39 & $<0.001$ \\
Hair zinc levels & 0.58 & $<0.001$ \\
\hline
\end{tabular}

at birth $\geq 48 \mathrm{~cm}, 53$ study subjects (53\%) had exclusive breastfeeding, 56 study subjects (56\%) had hair zinc level $\geq 198$ ppm, 53 study subjects (53\%) had normal height, 55 study subjects (55\%) had normal developmental. 
Sari et al./ Predictors of Stunting and Developmental Disorders

\section{The result of bivariate analysis}

Table 3 showed that maternal MUAC ( $\mathrm{r}=$ o.12; $\mathrm{p}<0.001)$, birth weight $(\mathrm{r}=0.29$; $\mathrm{p}=$ 0.042), birth length ( $\mathrm{r}=0.37 ; \mathrm{p}=0.011)$, breastfeeding ( $\mathrm{r}=0.08 ; \mathrm{p}=0.033)$, and hair zinc levels $(\mathrm{r}=0.58 ; \mathrm{p}<0.001)$ had positive effect on the development of the children and they were statistically significant. Stunting $(\mathrm{r}=0.39 ; \mathrm{p}<0.001)$ had negative effect on the development of the children and it was statistically significant.

Table 4. Bivariate analysis of maternal determinant factors and hair zinc levels as predictors of stunting

\begin{tabular}{lcc}
\hline Independent Variables & $\mathbf{r}$ & $\mathbf{p}$ \\
\hline Breastfeeding & -0.12 & $<0.001$ \\
Length at birth & -0.73 & $<0.001$ \\
Hair zinc levels & -0.16 & 0.006 \\
\hline
\end{tabular}

Table 4 showed that breastfeeding $(\mathrm{r}=$ $0.12 ; \mathrm{p}<0.001)$, birth length $(\mathrm{r}=-0.73 ; \mathrm{p}$ $<0.001)$, zinc levels $(b=-0.16 ; p=0.006)$ had negative effect on stunting and were statistically significant.

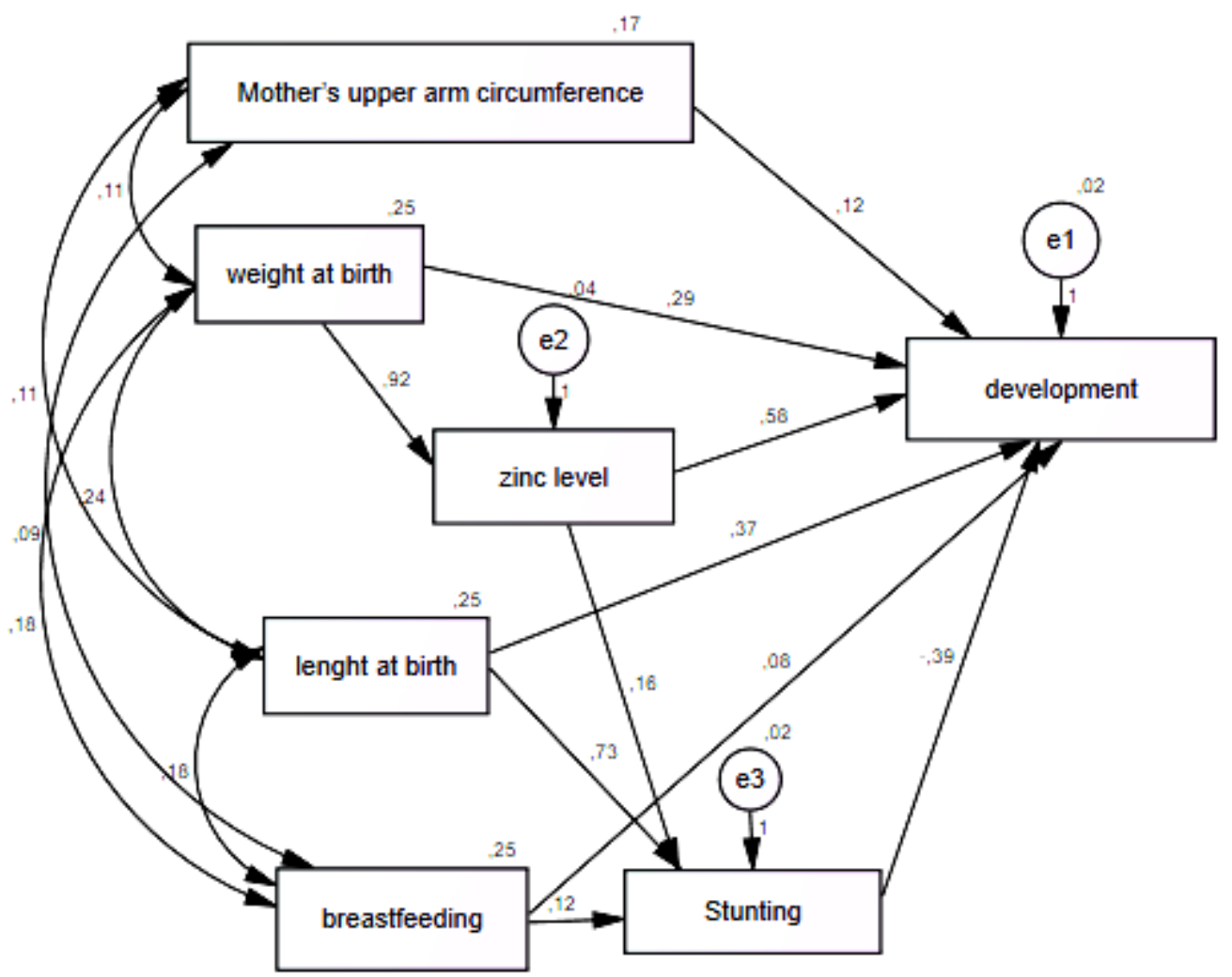

Figure1. Path analysis structural model

Figure 1 showed the structural model after being estimated using IBM SPSS AMOS 22 so that the value was obtained as shown in the figure. The indicator that showed the suitability of the path analysis model, such as Table 5 also showed the goodness of fit measure (a measurement of model fit) found that the results of the CMIN fit index were 6.32 with $\mathrm{p}=0.28>$ 0.05; NFI $=0.99 \geq 0.90$; CFI $0.99 \geq 0.95$; RMSEA $=0.05 \leq 0.08$ which meant that the empirical model met the specified criteria and was stated following empirical data. 
Sari et al./ Predictors of Stunting and Developmental Disorders

Table 5. Path analysis results

\begin{tabular}{|c|c|c|c|c|c|}
\hline $\begin{array}{c}\text { Dependent } \\
\text { Variables }\end{array}$ & Independent Variables & b & SE & $\mathbf{p}$ & $\boldsymbol{\beta}$ \\
\hline \multicolumn{6}{|l|}{ Direct Effect } \\
\hline Child development & $\leftarrow$ Maternal MUAC & 0.12 & 0.36 & $<0.001$ & 0.10 \\
\hline \multirow[t]{5}{*}{ Development } & $\leftarrow$ Normal birth weight & 0.29 & 0.15 & 0.042 & 0.29 \\
\hline & $\leftarrow$ Length at birth (normal) & 0.37 & 0.15 & 0.011 & 0.37 \\
\hline & $\leftarrow$ Breastfeeding & 0.08 & 0.04 & 0.033 & 0.09 \\
\hline & $\leftarrow$ Stunting & -0.39 & 0.10 & $<0.001$ & -0.39 \\
\hline & $\leftarrow$ Zinc Levels (high) & 0.58 & 0.67 & $<0.001$ & 0.58 \\
\hline \multicolumn{6}{|l|}{ Indirect Effect } \\
\hline Zinc Levels & $\leftarrow$ Birth weight & 0.92 & 0.04 & $<0.001$ & 0.92 \\
\hline \multirow[t]{3}{*}{ Stunting } & $\leftarrow$ Breastfeeding & -0.12 & 0.04 & $<0.001$ & -0.12 \\
\hline & $\leftarrow$ Birth length & -0.73 & 0.06 & $<0.001$ & -0.73 \\
\hline & $\leftarrow$ Zinc level & -0.16 & 0.06 & 0.006 & -0.16 \\
\hline \multicolumn{6}{|l|}{ Model Fit } \\
\hline \multicolumn{6}{|l|}{$\mathrm{CMIN}=6.32$} \\
\hline \multicolumn{6}{|l|}{$\mathrm{p}=0.28$} \\
\hline \multicolumn{6}{|l|}{ GFI $=0.98(\geq 0.90)$} \\
\hline \multicolumn{6}{|l|}{$\mathrm{NFI}=0.99(\geq 0.90)$} \\
\hline \multicolumn{6}{|l|}{$\mathrm{CFI}=0.99(\geq 0.95)$} \\
\hline \multicolumn{6}{|c|}{ RMSEA $=0.05(\leq 0.08)$} \\
\hline \multirow{2}{*}{\multicolumn{6}{|c|}{$\mathrm{b}=$ unstandardized path coefficient }} \\
\hline & & & & & \\
\hline
\end{tabular}

From Table 5, it could be seen that child development were directly affected by maternal MUAC, stunting, birth weight, birth length, breastfeeding, and hair zinc levels.

Maternal MUAC increased child development by 0.12 units $(b=0.12 ; \mathrm{SE}=$ o.36; $\mathrm{p}<0.001$ )

Stunting reduced child development by 0.39 units $(b=-0.39 ; \mathrm{SE}=0.10 ; \mathrm{p}$ $<0.001$ )

Bbirth weight increased child development by 0.29 units $(b=0.29 ; \mathrm{SE}=$ $0.15 ; \mathrm{p}=0.042$ )

Birth length increased child development by 0.37 units $(b=0.37 ; \mathrm{SE}=0.15 ; \mathrm{p}=$ o.011)

Exclusive breastfeeding increased child development by 0.08 units $(b=0.08$; $\mathrm{SE}=0.04 ; \mathrm{p}=0.033$ )

Hair zinc levels increased child development by 0.58 units $(\mathrm{b}=0.58 ; \mathrm{SE}=$ 0.67 ; $<0.001$ )
Hair zinc levels was indirectly affected by birth weight. Birth weight increased zinc levels by 0.92 units $(b=0.92 ; S E=0.04 ; p$ $<0.001$ ).

Stunting was indirectly affected by birth weight, breastfeeding, birth length, and zinc levels.

Every one unit increase in breastfeeding would reduce stunting by 0.12 units. ( $b=-0.12 ; \mathrm{SE}=0.04 ; \mathrm{p}<0.001$ )

Every one unit increase in length at birth would decrease stunting by 0.73 units. $(b=-0.73 ; \mathrm{SE}=0.06 ; \mathrm{p}<0.001)$

Every one unit increase in hair zinc levels would reduce stunting by 0.16 units. $(b=-0.16 ; S E=0.06 ; p=0.006)$.

\section{DISCUSSION}

1. Positive effect of maternal MUAC on the child development

Based on the results of the study, there is a direct positive effect between maternal 
MUAC on child development $(b=0.12 ; p<$ 0.001) which is significant.

This study result is in line with the study result by Nurahmawati et al., (2017), which found that there was a direct positive effect between the size of pregnant women's mother's upper arm circumference on the weight of the newborn. Another study, according to Ekayani (2014) also showed that maternal MUAC $<23.5$ have 5 times the risk of giving birth to babies with LBW $(\mathrm{OR}=5.54$; 95\% CI= 2.65 to 11.60$)$. According to Par'i et al., (2017) it was found that pregnant women with maternal MUAC $<23.5 \mathrm{~cm}$ will have a risk of giving birth to babies who were malnourished and, in the future, will make the baby sick more easily.

The LBW condition experienced by a baby will have several impacts on its development stage in the future. According to the study result by Shenkin et al., (2004) it was found that babies with a history of LBW had a risk of experiencing abnormal brain structures and brain signals when compared to normal birth weight babies. This would affect the maturity and development of the child in the future.

The results of other studies by Rosyidah \& Trias (2018) show that there was a significant difference between the development of children with a history of LBW and normal birth weight. In addition, the study results by Erika \& Amir (2009) showed that there was a significant relationship between birth weight, development, and outcome $(p=0.0001)$. The result of this study indicated that the aspects of development that experience delays are aspects of language speaking and social independence.

Based on the study results by Nasikhah \& Margawati (2012), it was found that the condition of pregnant women with low nutritional status, anemia would be at risk of giving birth with LBW, and this condition would have the risk of causing stunting in children under five. It was due to the condition of children under five with a history of LBW will experience growth retardation which will have an impact on their future if they do not receive adequate nutritional support, poor health services and suffer from recurrent infectious diseases (Indriani et al., 2018). This condition will cause the risk of stunting in children under five.

Besides, the results of other studies according to Rahayu, et al., (2018) also support the study results above, i.e. that there was a positive effected of Low Birth Weight on stunting. The growth and development of children with a history of low birth weight will develop more slowly when compared to babies with normal birth weight. The study results by Rabaoarisoa et al., (2017) show that babies with a history of LBW 1.6 times, in which the condition of stunting occurs from the time when the babies are in the womb to the age of 2 years old.

\section{Positive effect of birth weight on the child development}

The results of this study found that there is zinc levels increased birth weight in infants $(b=0.92 ; p<0.001)$ and child development $(b=0.58 ; p<0.001)$.

The results of this study are in line with Upadhyay et al., (2019), which conduct a meta-analytic study in South Asia, found that children who have a birth weight < 2000 grams, have cognitive and motoric development disorders when compared to normal birth weight. This condition is also in line with data on neurodevelopmental disorders in developing countries, which states that children with a history of LBW are at risk for lower cognitive abilities, tendencies to have fewer academic grades, have mental development disorders, emotional and behavioral disorders, and other 
Sari et al./ Predictors of Stunting and Developmental Disorders

developmental delays when compared with children with normal birth weight (Orchinik et al 2017)

Neurodevelopmental disorders that occur in children with a history of LBW are associated with cerebral disorders, cystic periventricular leukomalacia, intraventricular bleeding, decrease in total brain volume, and decrease in the number of cells and myelin. Besides, the brain consistency of children with a history of LBW will also have disturbances, it was indicated by the disruption of neural migration, disruption of dendrite processes, and the inefficiency of the work system in the neural network (Miller, Huppi and Mallard, 2016)

Children with a history of LBW have lower zinc levels when compared to children with a history of normal birth weight. This condition was associated with the condition of pregnant women who also experience micronutrient deficiencies, one of which is zinc deficiency. This deficiency could cause LBW and IUGR. Lower zinc levels in the mother can lead to a decrease in placental transport and zinc supply to the fetus (Black (1998) in Jyotsna et al., 2015). Zinc deficiency harms the endocrine system, thereby causing growth failure in a child. Zinc has an important role in various biological activities including maintenance of cell form and function, protein synthesis, nucleic acid metabolism, and immune function by acting as a co-factor for the production of 200 enzymes such as phosphatase, metalloproteinase, oxide-reductase, and transferase (Jyotsna et al., 2015).

Zinc deficiency during pregnancy could cause growth and development delays in children because zinc deficiency could affected the immune system. In addition, zinc in the body also plays a role in regulating IGF-I activity in the formation of osteoblasts, which has a role to regulate bone growth (Domenech, 2001 in Jyotsna et al., 2015).

\section{The effect of length at birth on the development}

There was a positive effect of birth length on stunting $(b=0.73 ; p<0.001$. Stunting had positive effect on child development $(b=0.39 ; p<0.001)$.

The study results by Andini et al., (2020) state that there was a significant relationship between the baby's length at birth and stunting. This condition was caused by babies who have a low birth length from an early age can experience a condition of failure to grow (growth faltering) in the future, so they wouldl not be able to achieve optimal growth in the future. According to Walyani (2015) the condition of malnutrition experienced by pregnant women would continue to the condition of malnutrition experienced by the baby, if it was not supported by adequate intake, then a child will not grow according to his age.

Another study result by (Permatasari \& Sumarmi (2018) shows that there was a significant difference between a history of length at birth as well as stunting and nonstunting $(\mathrm{p}=0.03)$. The other study results according to Damayanti et al., (2017), in which babies born with a low birth length category are at risk of stunting 2.9 times greater than babies born with normal body length. According to Wijayanti \& Sumarmi, (2017), pregnant women with less micronutrient intake will cause malnutrition in children under five. This will have an impact on growth and development disorders in children under five. This condition, if left untreated, would lead to stunting.

Stunting conditions experienced by a baby will cause developmental disorders. It was in line with the study results by Probosiwi et al., (2017) which showed that a 
child who was stunting would have a 3.9 times risk of developmental disorders. The results of this study are in line with the study by Muhoozi et al., (2016) which states that children with stunting affected cognitive, motoric, and language development. It was because the condition of stunting would have an effect on brain development directly and affect physical growth. Besides, the condition of stunting will also affect the low tricepsurae muscle development which causes motor skills to be different when compared to normal children (Solihin et al., 2013).

\section{Effect of breastfeeding on child development}

There is a positive effect of breastfeeding on stunting $(b=0.12 ; p<0.001)$. There was positive effect of stunting on the child development $(b=0.39 ; p<0.001)$. Thus, it can be concluded that there is an indirect and positive effect of breastfeeding on the development of the children.

This study result was in line with the results of a study in Rwanda by Nshimyiryo et al., (2019) which state that babies who are exclusively breastfed for 6 months have a lower risk of stunting, whereas the stunting will increase in Rwanda when children under five get inadequate nutritional intake during complementary feeding. This condition was caused by not having sufficient knowledge to provide adequate complementary feeding for babies so that the fulfillment of micronutrients becomes inadequate.

Stunting condition experienced by children, due to not getting adequate breastfeeding, would affect the development of a child. It was in line with the study results by Maria Goreti Pantaleon and Hamam Hadi, (2015) which state that there was a significant relationship between the incidence of stunting and motor development of children under the age of two. The study results were consistent with the opinion that stunted children experience slow and low skeletal growth. The condition of stunting was the result of a long period due to unmet food needs which increase morbidity, and usually found in countries with poor economic conditions (Gibson, 1990).

\section{Effect of zinc levels on the development}

Hair zinc levels had positive association with stunting ( $b=0.16 ; p=0.006)$. Stunting had positive association with child development $(b=0.39 ; p<0.001$.

The study results by Rahmawati A dan Yekti W (2012) state that hair zinc levels had a significant effect on the growth of children's nutritional status as measured by a child's z score HAZ. Hair zinc levels represent long-term Zinc status and did not rapidly experience fluctuations associated with food intake and food variation (Hambidge, 2003). Head hair could be used as a biopsy material for population screening at risk of deficiency of trace elements such as zinc. Head hair represents the trace element's status chronically.

Hair zinc levels are a biomarker to detect zinc deficiency, where hair zinc will be taken as endogenous zinc to meet zinc needs (Gibson, 2005). Zinc was a micronutrient that plays an important role in cell growth, especially for producing enzymes needed for the synthesis of RNA and DNA. Zinc, which was found in the brain, functions to bind to proteins thus contributing to the formation of brain structure and function. Zinc deficiency can cause malformations and failure of brain structures such as anencephaly, microcephaly, and hydrocephalus to occur. In addition, zinc deficiency can cause behavioral problem disorders, short memory skills, decreased cognitive function, and can even cause emotional disturbances (Black, 1998). 
Sari et al./ Predictors of Stunting and Developmental Disorders

\section{Effect of stunting on child development}

The results of the study carried out in the working area of Gurah Public Health Center are obtained first, there is a positive effect of stunting on the development of children directly. Figure 1 shows that there is a direct and positive effect of stunting on the children development $(b=0.39 ; p<0.001)$.

The condition of stunting starts in the womb and lasts until at least 2 years old, if allowed to continue, this condition can cause developmental disorders (de Onis and Branca, 2016). It was in line with the study results by Probosiwi et al., (2017) which shows that a child who is stunting will have a 3.9 times risk of experiencing developmental disorders.

The results of this study are in line with a study by Muhoozi et al., (2016) which states that children with stunting affect cognitive, motoric, and language development. It was caused by the condition of stunting will have an effect on brain development directly and affect physical growth. Besides, the stunting condition would also affected the low tricepsurae muscle development, causing motor skills to be different when compared to normal children (Solihin et al., 2013)

Based on the explanation above, it can be concluded that the developmental disorders on a child were affected by maternal MUAC, birth weight, birth length, breastfeeding, stunting, and hair zinc levels. Hair zinc levels were affected by birth weight. Stunting was affected by breastfeeding, birth length, and zinc levels. By obtaining the results of this study, it is hoped that further researchers can provide interventions to prevent and overcome the condition of stunting by providing interventions to increase zinc levels and increase knowledge about exclusive breastfeeding. Good nutritional preparation before pregnancy is an effort to give birth to quality future generations.

\section{AUTHOR CONTRIBUTION}

Nunik Ike is the main researchers who selectrd the topic, collected research data, analyzed data, and wrote up the manuscript. Estin Gita, selected the topic, managed data collection, and interpreted the result.

\section{CONFLICT OF INTEREST}

There is no conflict of interest in this study.

\section{FUNDING AND SPONSORSHIP}

This work was supported by the Directorate of Research and Community Service (DRPM), Deputy for Strengthening Research and Development, Ministry of Research, Technology/National Research and Innovation Agency of the Republic of Indonesia.

\section{ACKNOWLEDGEMENT}

We are very grateful to the Directorate of Research and Community Service (DRPM), Deputy for Strengthening Research and Development, Ministry of Research, Technology/National Research and Innovation Agency of the Republic of Indonesia.

\section{REFERENCE}

Andini V, Maryanto S, Mulyasari I (2020). Hubungan panjang badan lahir, berat badan lahir dan pemberian ASI eksklusif terhadap kejadian stunting pada baduta usia 7-24 bulan di Desa Wonorejo Kecamatan Pringapus Kabupaten Semarang. Jurnal Gizi Dan Kesehatan. 12(27): 49-58. doi: 10.35473/jgk.v12i27.60.

Bening S, Margawati A, Rosidi A (2017). Zinc deficiency as risk factor for stunting among children aged 2-5 years. Universa Medicina. 36(1): 11. 
Sari et al./ Predictors of Stunting and Developmental Disorders

doi: $\quad 10.18051 /$ univmed.2017.v36.1118.

Black MM (1998). Zinc deficiency and child development. Am J Clin Nutr. 68(2). doi: 10.1093/ajen/68.2.464S.

Damayanti RA, Muniroh L, Farapti F (2017). Perbedaan tingkat kecukupan zat gizi dan riwayat pemberian asi eksklusif pada balita stunting dan non stunting. Media Gizi Indonesia. 11(1): 61. doi: 10.20473/mgi.v11i1.61-69.

Danaei G, Andrews KG, Sudfeld CR, Fink G, McCoy DC, Peet E, Sania A, et al. (2016). Risk factors for childhood stunting in 137 developing countries: A comparative risk assessment analysis at global, regional, and country levels. PLoS Med. 13(11): e1002164. doi: 10.1371/journal.pmed.1002164.

Ekayani NPK (2014). Faktor Sosiodemografi, medis maternal, status gizi dan pemeriksaan antenatal yang rendah meningkatkan risiko kejadian berat badan lahir rendah di Kota Mataram Propinsi Nusa Tenggara Barat. Media bina ilmiah. 8(4): 24-32.

Erika KA, Amir NA (2009). The relations between birth weight and child development under five years in Puskesmas Goarie Sub-District Marioriwawo. Indonesian Contemporary Nursing Journal. 3(2): 15-23.

Gibson RS (1990). Anthropometric measurement of body composition. Principles of Nutritional Assessment. New York: Oxford University Press.

Gibson RS (2005). Principles of nutritional assessment. Oxford university press, USA.

Guide I (2012). Interpretation guide: $\mathrm{Nu}-$ trition landacape information system (NLIS). 1-51. doi: 10.1159/00036278o.Interpretation.

Hambidge M (2003). Biomarkers of trace mineral intake and status. Journal of
Nutrition. 133(3): 948-955. doi: 10.1093/jn/133.3.948s

Indriani D, Dewi YLR, Murti B, Qadrijati I (2018). Prenatal factors associated with the risk of stunting: A multilevel analysis evidence from Nganjuk, East Java. J Matern Child Health. 03(04): 294-300. doi: 10.26911/thejmch.2018.03.04.07.

Jyotsna S, Amit A, Kumar A (2015). Study of serum zinc in low birth weight neonates and its relation with maternal zinc. J Clin Diagn Res. 9(1): SCo1SCo3. doi: 10.7860/JCDR/2015/10449.5402.

Kesehatan Badan Penelitian dan Pengembangan Kesehatan Puslitbang Humaniora dan Manajemen Kesehatan KR (2018). Hasil Utama Riskesdas 2018 Provinsi Jawa Timur. 1-82.

Li C, Zhu N, Zeng L, Dang S, Zhou J, Yan H (2016). Effect of prenatal and postnatal malnutrition on intellectual functioning in early school-aged children in rural western China. Medicine, 95(31): e4161. https://doi.org/10.1097/MD.0000000000004161.

Pantaleon MG, Hadi H, Gamayanti IL (2015). Stunting berhubungan dengan perkembangan motorik anak di Kecamatan Sedayu, Bantul, Yogyakarta. Jurnal Gizi dan Dietik Indonesia. 3(1): 10-21.

Miller SL, Huppi PS, Mallard C (2016). The consequences of fetal growth restriction on brain structure and neurodevelopmental outcome. J Physiol. 594(4): 807-823. doi: 10.1113/JP271402.

Muhoozi GK, Atukunda P, Mwadime R, Iversen PO, Westerberg AC (2016). Nutritional and developmental status among 6- to 8-month-old children in southwestern Uganda: a cross-sectional study. Food \& nutrition research. 60: 30270. https://doi.org/10.3402- 
Sari et al./ Predictors of Stunting and Developmental Disorders

/fnr.v60.30270

Nasikhah R, Margawati A (2012). Prevalensi stunting di Jawa Tengah kejadian tertinggi di Kecamatan Semarang Timur. Journal of Nutrition College. 1(1): 176-184. Available at: ejournals1.undip.ac.id.

Nshimyiryo A, Hedt-Gauthier B, Mutaganzwa C, Kirk CM, Beck K, Ndayisaba A, Mubiligi J, et al. (2019). Risk factors for stunting among children under five years: a cross-sectional population-based study in Rwanda using the 2015 Demographic and Health Survey. BMC public health, 19(1): 175 . https://doi.org/10.1186/s12889-0196504-z.

Nurahmawati D, Salimo H, Dewi YLR (2017). Effects of maternal education, psychosocial stress, nutritional status at pregnancy, and family income, on birthweight in Nganjuk, East Java. J Matern Child Health. 02(04): 324334. doi: 10.26911/thejmch.2017.02.04.04.

de Onis M, Branca F (2016). Childhood stunting: A global perspective. Matern Child Nutr. 12: 12-26. doi: 10.1111/mcn.12231.

Orchinik LJ, Taylor HG, Espy KA, Minich $\mathrm{N}$, Klein N, Sheffield T, Hack M (2011). Cognitive outcomes for extremely preterm/extremely low birth weight children in kindergarten. J Int Neuropsychol Soc. 17(6): 1067-1079. https://doi.org/10.1017/S135561771100107X

Par'I HM, Wiyono S, Harjatmo TP (2017). Penilaian status gizi. Jakarta Selatan: Pusat Pendidikan Sumber Daya Manusia Kesehatan.

Park SG, Choi HN, Yang HR, Yim JE (2017). Effects of zinc supplementation on catch-up growth in children with failure to thrive. Nutrition research and practice. 11(6): 487-491. https://doi.org/10.4162/nrp.2017.11.6 .487 .

Permatasari DF, Sumarmi S (2018). Differences of born body length, history of infectious diseases, and development between stunting and non-stunting toddlers. Jurnal Berkala Epidemiologi. 6(2): 182. doi: 10.20473/jbe.v6i22018.182-191.

Probosiwi H, Huriyati E, Ismail D (2017). Stunting dan perkembangan anak usia 12-6o bulan di Kalasan. Berita Kedokteran Masyarakat. 33(11): 559. doi: 10.22146/bkm.26550.

Remonja CR, Rakotoarison R, Rakotonirainy $\mathrm{NH}$, Mangahasimbola RT, Randrianarisoa $\mathrm{AB}$, Jambou $\mathrm{R}$, et al. (2017). The importance of public health, poverty reduction programs and women's empowerment in the reduction of child stunting in rural areas of Moramanga and Morondava, Madagascar. PloS one. 12(10): eo186493. https://doi.org/10.1371/journal.pone.0186493

Rahayu RM, Pamungkasari EP, Wekadigunawan $C$ (2018). The biopsychosocial determinants of stunting and wasting in children aged 12-48 months. J Matern Child Health. 03(02): 105118. doi: 10.26911/thejmch.2018.03.02.03.

Rahmawati A, Yekti W (2012). Perbedaan kadar zinc rambut berdasarkan derajat stunting pada anak usia 6-9 tahun. Journal of Nutrition College. 1(1): 365-372.

Shenkin SD, Starr JM, Deary IJ (2004). Birth weight and cognitive ability in childhood: A systematic review. Psychol Bull. 130(6): 989-1013. doi: 10.1037/0033-2909.130.6.989.

Solihin RDM, Anwar F, Sukandar D (2013). Kaitan antara status gizi, perkem- 
Sari et al./ Predictors of Stunting and Developmental Disorders

bangan kognitif, dan perkembangan motorik pada anak usia prasekolah (relationship between nutritional status, cognitive development, and motor development in preschool children). The Journal of Nutrition and Food Research. 36(1): 62-72.

Rosyidah S, Mahmudiono T (2018). Hubungan Riwayat BBLR Dengan Pekembangan Anak Prasekolah (Usia 4-5 Tahun) Di TK Dharma Wanita III Karangbesuki Malang. Amerta Nutrition. 2(1): 66-73. doi: 10.2473/amnt.v2i1.2018.66-73.

Upadhyay RP, Naik G, Choudhary TS, Chowdhury R, Taneja S, Bhandari N, Martines JC, et al. (2019). Cognitive and motor outcomes in children born low birth weight: a systematic review and meta-analysis of studies from South Asia. BMC pediatrics. 19(1): 35 . https://doi.org/10.1186/s12887-0191408-8

Walyani ES (2015). Perawatan kehamilan dan menyusui anak pertama agar bayi lahir dan tumbuh sehat. Yogyakarta: Pustaka Baru.

WHO, UNICEF, Group WB (2018). Levels and Trends in Child Malnuutrition.

Wijayanti R, Sumarmi S (2017). Pertumbuhan anak dari ibu yang mendapat suplemen multi-mikronutrien dan anak dari ibu yang mendapat suplemen besi folat selama hamil (Studi follow up di Kabupaten Probolinggo, Jawa Timur). Indones $\mathrm{J}$ Public Health. 11(1): 1. doi: 10.20473/ijph.v11i1.2016.1-13. 